УДК 338.486: 005.591.6 (438.23)

\title{
SCENARIOS OF THE FUTURE - MODELLING OF INNOVATIVE TOURIST PRODUCTS
}

\author{
Z. Zontek, E. Lipianin-Zontek \\ University of Bielsko-Biala, Poland
}

\begin{abstract}
The aim of this article is to indicate the directions of the development of tourist sector innovativeness in the south region of Silesian Province. In the article was self-characterized the essence of modelling innovative products during the cycle of product life. There were presented chosen results of research in region and scenario planning method, used for indication of main changes in tourist sector - with special pressure on the innovativeness.
\end{abstract}

Key words: Tourist products, Innovation, Future

\section{The essence of innovation in tourist sector}

A formation of innovative products on the level of a company, on the local plane, has an impact on a development of competitive tourist products of the region, allows for the tourist activation, initiates the formation of partnership concerning the problem of innovation, and also brings about the effect of cooperation.

The following study aims at indicating the basic terms that refer to the innovation of tourist products, and presenting the possible scenarios of development which consider the implementation of innovative tourist products. The scenarios were drawn up for the southern sub-region of Silesia province on the basis of interviews conducted among the identified companies of the region.

The term innovation is strictly connected with the notions such as: novelty, output, changes, reforms, enterprise, or at present "management of knowledge". However, the notions do not coincide with each other. The output refers to the creation of new ideas (from Greek: the art of invention), and its main domain of interest are the processes and methods of creative thinking. However, the innovation does not require just new discoveries, one can introduce solutions that already exist.

As the term is popularly understood, the innovation implies a new solution of certain problems, issues which involve a change of actual state and has an important part in a development of the specific field, for example technology, organization, management or ecology (12, p. 128). One should emphasize that the term "Innovation" does not necessarily mean "new" in the world, it can also denote "new" for a given economic unit (2, p. 693-716).

The pioneer, in the field of the terminology referring to innovation and innovation character, is J.A. Schumpeter who defined innovations as the usage and popularization of new solutions in practice $(10$, p. 60$)$. He distinguished, in their introductory process, three sequences following in succession:

- Invention; in other words finding possibilities of using the new concepts in practice, discoveries and other results of a scientific activity.

(C) Zontek Z., Lipianin-Zontek E., 2013 
- Innovation; a materialization of inventions- a fulfilment of an invention in the shape that functions in practice.

- Diffusion (imitation)- these are changes of imitational or inventive character, having a continuous course, however the innovations refer to changes which do not show the continuous character, that is why they are unique and original.

The concept of triad by Schumpeter differentiates the term of invention and innovation, which is understood as the process of implementation and practical usage of a new service, a procedure or standard of behaviour- if they show the features of novelty $(1, \mathrm{p} .53)$. The cycle of innovation ends with so called diffusion of innovation which is distinguished as the transfer of innovation within the branches of economy, as well as its adaptation (spatial and inter branch-like diffusion). Schumpeter differentiated five categories of innovation:

- introduction of a service or vital improvement of the quality of existing service;

- introduction of a new or essentially modernized method of production;

- a creation of a new segment on the market or an access to a geographically new market;

- introduction of a new type of company organization (10, p. 104).

According to Schumpeter, innovations denote "changes" which are subject to the process of commercialization, in other words the products/services or processes, which have the economic value, are the effect of introducing innovations $(13$, p. 80-81). In the similar way Pavitt, Tidd, Bessand who describe the innovations as a process that involves a development of new ideas to introduce products or processes to a turnover (8, p. 343-374). However, P.F. Drucker indicates that an innovation should be treated as the instrument of enterprise (3, p. 54-55). The innovative activities can appear in projects, marketing activities, products, a price or service for a customer, organization or methods of management.

\section{Modelling of innovations stimulation}

There are unique models of forming and stimulating innovations in the field of tourism. A tourist company which looks for possibilities of introducing new product and processlike solutions deserve to be called the innovative company. The innovative activity may have a diverse character depending on the specificity of a company. Some of the companies conduct strictly defined innovative projects, for example as they create and introduce a new product, whereas other ones make constant improvements in their products, processes and activities. Both types of subjects can be recognized as the innovative ones: the innovation may rely on implementing one major change or a series of smaller, incremental changes, which form together a meaningful change. Even the companies which tend to search new methods of running a business deserve to be called "innovative" (6, p. 43-45).

The terminology that refers to a division of innovation, and also the one which considers a division of sources in creating innovative tourist products, is rich and multilevel. This study was based on the innovative division of A.M. Hjalager, worked out on the basis of Abernathy and Clark's model (5, p. 466-467). The author differentiates four main innovative groups: regular, recessive, radical and revolutionary, considering two essential factors: external (market connections) and internal (competence). The innovation division and the choice of determinants give the basis for a study of programmes of the future method for a development of tourism which considers a formation of innovative tourist products. 
The effects of innovative activities are strictly dependant on a type of implemented innovation. The creation of innovative tourist products may include simple modifications of existing products, processes and practices (which can be new for a company, but not necessarily for the tourist business), but on the other hand it refers to fundamentally new products and processes (which are new both for business and a tourist company).

A realization of the idea should engage the whole range of scientific, organizational, technological, marketing, financial and commercial activities, and the effects of the actions may lead to innovation in the following fields (7, p. 1143-1144):

- Product-like innovations, which give rise to innovative products, tourist services and in other economic sectors;

- Administration and process-like innovations, which aim to improve the process of tourist services and procedures of administration in tourist companies and clusters;

- Information innovations - a usage of brand- new information and promotion channels, innovations of information system within a cluster;

- Institutional innovations - new directions of public-legal partnership and support of public system for tourist companies. Institutional innovations include particularly a creation of new organizational solutions, such as:

a) cooperative models ( network, consortia, centres, ...)

b) consolidation models (fusions, unions, and institutional federations, ...)

c) changes of name (new logo) - re-branding.

The realization of an idea should activate the whole range of scientific actions: organizational, technological, financial and commercial ones. The creation of innovative tourist products can include simple modifications of existing products, processes and practices(which can be new for a company, but not necessarily for the tourist business) from one hand, and fundamentally new products and processes from the other hand ( which are new both for business and tourist company). The detailed definition of innovation was published by OECD in the series of handbooks called Oslo Manual. The core of the problem is putting the novelty into practice, which comes down to offering of a new product or service on the market, and in relation to a new process, organization or marketing methods, to their usage in the current activity of a businessman. The innovation can be a result of one's own empiric and developmental business, cooperation with other entrepreneurs or institutions, or a result of the know-how purchase.

However, one should assume that the innovation of tourist companies is gradated, used with different intensity and scale. The innovation of tourist companies is also dependent on the type of business and location in the tourist field. Therefore, it is reasonable to point out the definitions, where the innovation of tourist companies is defined as the ability and motivation for a research and commercial usage of any scientific results of studies, new concepts, ideas that result in an increase of the level of modernity and reinforcement of the competitive position of a company, or the realization of entrepreneur's ambitions.

One may indicate that there are also innovations in tourism which have organizational, technical, marketing, market, logistic, institutional, cultural or psychological character (4, p. 1-12). The potential fields of innovation in tourist companies are the complementation of presented forms of innovation in tourism. Among the basic fields, one may distinguish:

- products (signs of the innovative activity: a creation of new, trade mark tourist 
products; improvement, modernization of current products/services - a modification of structure of the service package, their qualities and prices; introduction of current products on new markets);

- organization and administration (signs of the innovative activity: implementation of new techniques, methods and instruments of a company dynamic administration; formation of pro innovative culture of a tourist company; formation of a flexible organizational culture; diffusion of knowledge and information; implementation of the methods of stimulation in worker production - one of the best known are brainstorming or synectics based on the rule of free associations);

- finances (signs of the innovative activity: usage of legal instruments for incidence reduction, for example leasing, digressive methods of amortization; usage of integrated systems supporting administration, e.g. controlling);

- marketing (signs of the innovative activity: systematic research and analysis of weak and strong points of a company; systematic research and analysis of a competitor situation and other elements of the environment; knowledge of tourist needs, registration of their changes; testing of the approval of new products; usage of intensive instruments;

- sales activation; creation of competitive and flexible, but at the same time wellgrounded economic price policy, which is attractive for tourists; implementation of new methods of tourist acquisition; a creation of a company image; formation of new segments on the market);

- human resources (signs of the innovative activity: development of the motivating system that causes creativity in workers, ability and tendency to innovation; overcoming qualms about changes; development of extensive training system and staff training; treating worker as an investment conditioning a development;

- relationships with the surrounding (signs of the innovative activity: development of relations (of cooperation) within different forms of cooperation with other companies clusters, strategic alliances; introduction of rules of quality management in relationships with surrounding);

- ecology (signs of the innovative activity: creation of pro ecologic forms of active leisure; elimination of the negative results of tourist activity; joint activities of tourist market subjects in the field of environmental preservation methods).

The processes of innovative tourist product creation more rarely restrict to a single company. It is motivated both, by the specificity of tourist sector (the companies are distinguished by a narrow specialization) and size of companies (the majority of companies in the sector are micro and macro ones). A good example in the tourist trade is the activity of accommodation objects, including hotels and pension houses which rarely have products and services that support and complete the activity in their basic profile, e.g. sports and recreational objects, services of free time organization and the like. The mentioned companies have to cooperate with other companies to satisfy a customer.

\section{Selected results of research referring to a development of innovative tourist products in the sub-region}

The aim of the cited above fragments of research (interview) was to show the possible scenarios of the tourist product development, including the implementation of innovations. 
The spatial range of the research involved the southern sub-region of Silesia province, including the second level of local government administration of Bielsko, Cieszyn, Żywiec, and the town Bielsko-Biała, characterized according to the second level of local government administration law. The research referred to tourist companies in tourist resorts: BielskoBiała, Szczyrk, Wisła, Ustroń, districts Jeleśnia and Milówka which are located in the area of Beskid Śląski, Beskid Żywiecki and Beskid Mały. The research was conducted at the turn of the 2010/2011 year. A random sample of 35 tourist companies was defined on the basis of the intentional choice from the operator, based on the telephone-address list. The scenarios of the tourist product development for "Beskidy" region were drawn up on the basis of the interviews.

Each customer of a tourist company has a dilemma, which is also a dilemma for managers, and it refers to the question, which element of the tourist product structure makes a tourist come to a given region. In spite of a development of cultural tourism in recent years, a considerable part of tourist movement is directed to relaxation, and the beauty of landscape matters greatly in meeting the need. Entrepreneurs indicated two basic elements: price and natural value. The majority of them indicate that it is the price (52\%) that determines a decision of using a tourist offer, the natural value a bit less $(36 \%)$. Since, they are the integrated part of tourist attractions and are an important issue in the creation of a tourist product for a tested sub-region.

\section{Chart 1. Factors which have an impact on decisions of a customer, as far as a tourist journey is concerned}

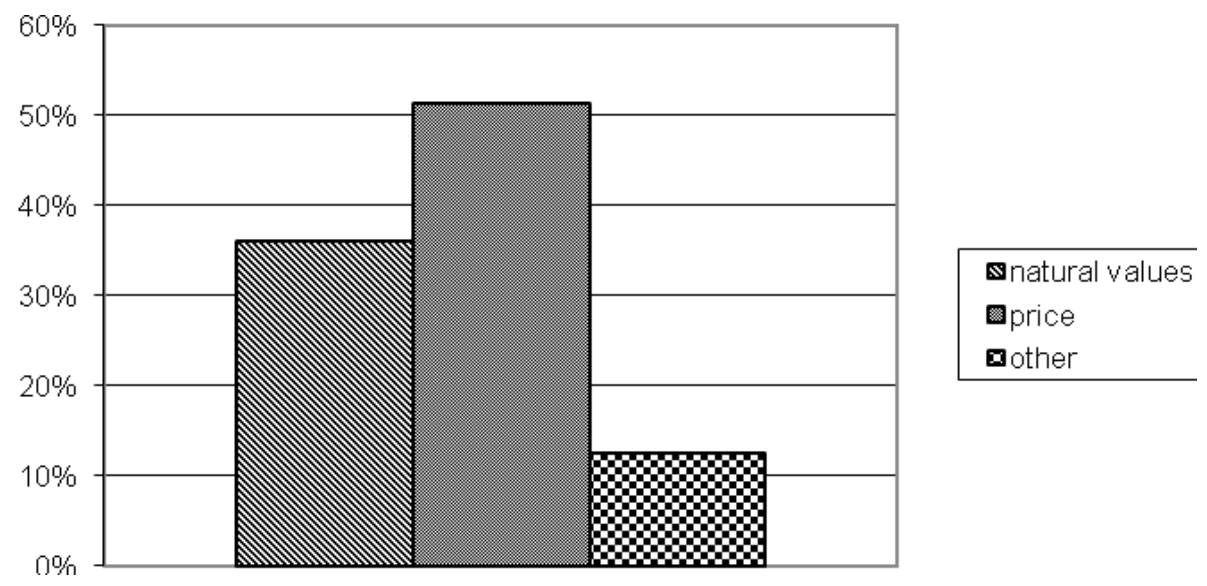

Source: the Author's own compilation, basing on result of research.

The entrepreneurs showed that the infrastructure has to develop in order to meet tourists' needs, and it should give satisfaction to both customers and owners. The more attractive place, the more eagerly it is visited by tourists, and higher prices are likely to be paid by them for the services. Some other features are noticed by companies, which have an influence on a decision of purchase: a developed recreational base, a land development and safety of a journey. 
Geographic and natural conditions of the region give a rise to a specialization of tourist companies ( $78 \%$ of indications). Obviously, it is the easiest way of the specialization which is successful and allows to avoid customer disorientation. The historical conditions take the second place -it means that monuments are less interesting than: the sun, a well prepared ski slope and landscape.

\section{Chart 2. Factors which have an influence on a specialization in tourist companies}

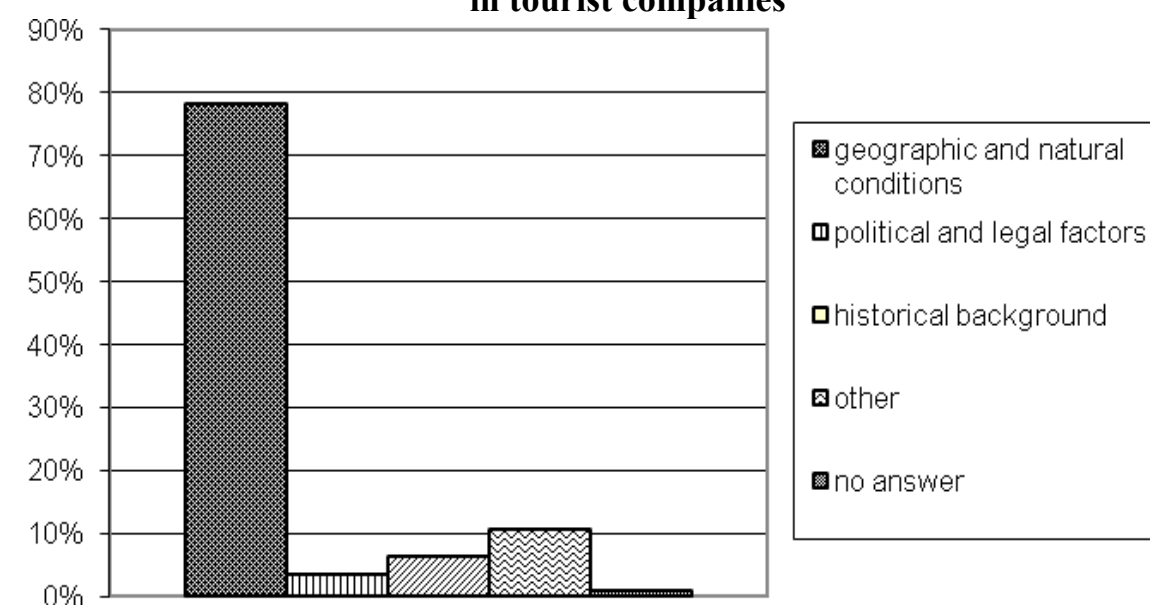

Source: the Author's own compilation, basing on result of research.

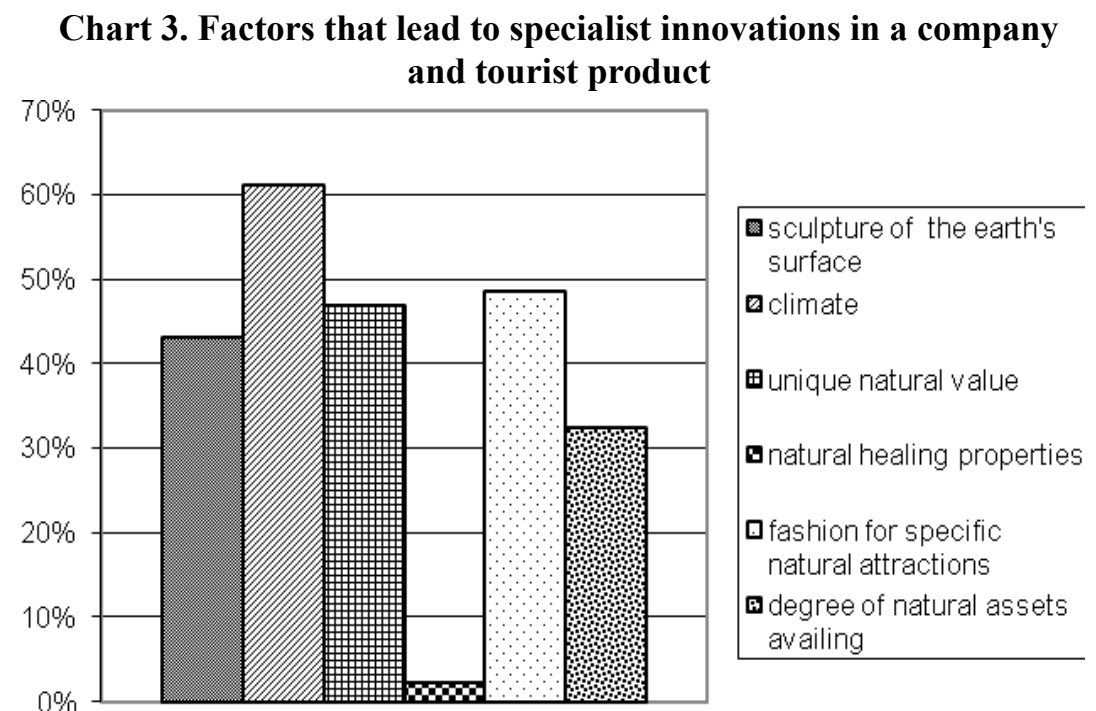

Source: the Author's own compilation, basing on result of research. 
A specialization of companies and an offered tourist product is first of all a consequence of climate (climate was indicated as the most important factor of the specialization, $61 \%$ of indications), a fashion for specific natural attractions (49\%) and a unique natural value $(47 \%)$, which means that a way of tourist product creation results from climatic circumstances, but also following the fashion and expansion of a tourist offer with unique attractions. Entrepreneurs showed that easiness in using attractions determines the group that the offer has to be directed to.

\section{The future scenarios of the innovative tourist product development for the region}

The scenarios of the tourist product development for the southern sub-region of Silesia province were drawn up on the basis of information obtained by the analysis of secondary resources and interviews. The programme method (scenario planning) was out by Royal Dutch/Schell, and allows for the analysis of possible situations, paying special attention to their influence on a market subject.

\section{Table 1. The course of the tourist product development in the southern sub- region of Silesia province - the optimistic and pessimistic scenario}

\begin{tabular}{|c|c|}
\hline & \\
\hline $\begin{array}{l}\text { - Strengthening of tourist attraction in basic trade mark } \\
\text { products of the region } \\
\text { - Creation of new products } \\
\text { - Extension of tourist attraction in the region by the } \\
\text { revitalisation of region towns } \\
\text { - Formation of new tourist infrastructure and modernization } \\
\text { of the existing one (accommodation, gastronomic, partner } \\
\text { one) } \\
\text { - Foundation of new legally protected areas and making them } \\
\text { available to tourism } \\
\text { - Introduction of new technologies and innovations which } \\
\text { facilitate and streamline the tourist movement service } \\
\text { - An increase of the amount of tourist companies that } \\
\text { generate new jobs } \\
\text { - Joint actions of tourist subjects in order to raise the quality } \\
\text { of tourist services } \\
\text { - A cooperation of tourist trade with domestic and foreign } \\
\text { scientific centres } \\
\text { - A cooperation of tourist trade with schools which run tourist } \\
\text { studies } \\
\text { - High interests of structural funds and other union join- } \\
\text { funding forms of tourist trade projects } \\
\text { - Successive implementation of new technologies, especially } \\
\text { information and pro ecological ones in tourist industry } \\
\text { - Extensive regional system of promotion } \\
\text { - A high number of domestic and foreign tourists who visit } \\
\text { the region }\end{array}$ & $\begin{array}{l}\text { - A lack of interest of trade mark } \\
\text { product development in tourist trade } \\
\text { - A competition in tourist trade, } \\
\text { instead of cooperation } \\
\text { - Traditionalism of economy in the } \\
\text { region, which is expressed by a lack } \\
\text { of recognition of tourist trade } \\
\text { - A lack or limited interest (in tourist } \\
\text { trade) of EU structural funds and } \\
\text { their devotion for a growth of } \\
\text { region attraction } \\
\text { - A limited interest (in tourist trade) } \\
\text { of innovations used in tourism } \\
\text { - Too slow adaptation of tourist } \\
\text { companies to EU requirements } \\
\text { (directives, standards) } \\
\text { - Non keeping up of tourist industry } \\
\text { in the region with the external } \\
\text { competition } \\
\text { - A low interest of structural funds } \\
\text { and other union join-funding forms } \\
\text { of tourist trade projects } \\
\text { - A lack of interest (in tourist } \\
\text { innovation trade) of new } \\
\text { technologies } \\
\text { - A wilfulness in the implementation } \\
\text { of modern systems in tourist } \\
\text { company administration }\end{array}$ \\
\hline
\end{tabular}
Source: the Authors' own compilation, basing on result of research. 
The aim of scenarios is to define the future and to have a better understanding of mechanisms that function in the surrounding. Scenario planning is the process that enables the organization to predict the way the surrounding will be shaped in the future. The pragmatic aim of the analysis is to select tendencies and factors in order to create several possible scenarios allowing for assessment of strategic options and possibilities. The scenarios were used for a definition of strategy assumption of innovative tourist product development in a subject region.

Table 2. The course of tourist product development in in the southern sub-region of Silesia province - the most probable scenario

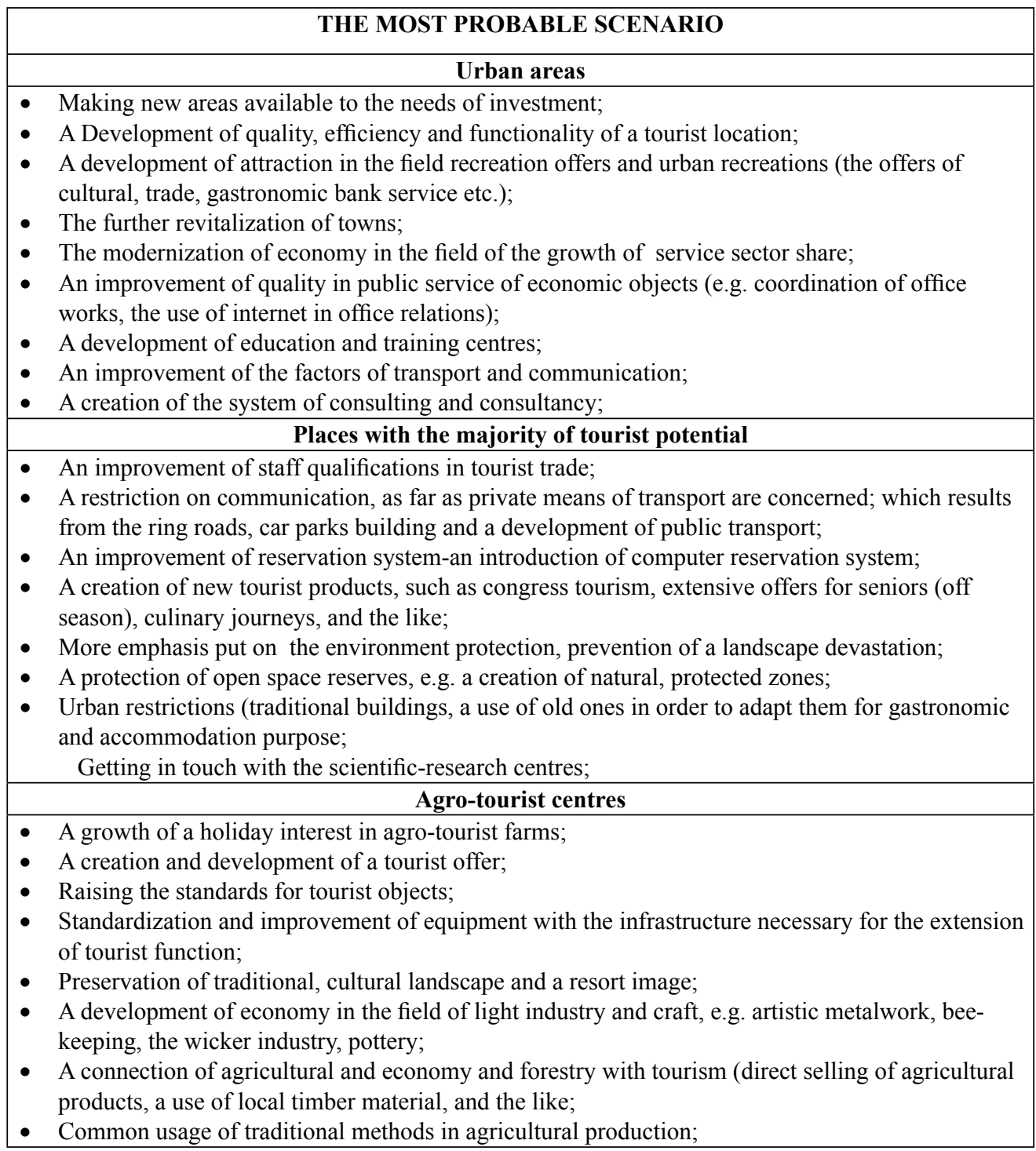




\section{Agricultural areas}

- An improvement of communication with regional centres (road building and modernization, maintenance of public communication);

- A Support of buildings which aims to preserve the traditional style and support of renovation;

- A study of the agriculture maintenance concept, including mountain agriculture (sheep pasturage, horse studs);

- A support of folk craftwork and traditional folk artistic work;

- An introduction of the alternative forms of administration in a region (ecological agriculture);

- A creation of the image of rural areas, as the ecologically clean; promotion of such regions;

Source: the Author's own compilation, basing on result of research.

The most probable scenario is extremely important, as far as the creation of the strategy of innovative tourist product development is concerned, especially with factors which have a strong impact on the development. It was divided into areas of tourist spatial product concentration, such as:

- urban areas, which refer to the place of industry localization, supplies of population and also the centres of administration;

- places with the majority of tourist potential, which possess rich and diversified tourist offer;

- agro-tourist places which have tourist offer and conditions for a further development;

- agricultural areas which form the basis for a development of rural tourism.

The factors described in the most probable scenario for the sub-region do not exhaust all the vital tendencies which may have an impact on innovation of separate tourist places. The conducted research indicates that arrangement of values in the whole region is uneven, as far as their potential is concerned. Thus there in a need of internal division for marketing reasons, so as the areas of similar values and tourist development could jointly create their product and conduct its promotion and distribution.

\section{Summary}

The drawn up scenarios lead to the formulation of innovative tourist product development plan for the southern sub-region of Silesia province. They assume:

- a need for formation of local tourist organization, which might join local governments, economic subjects and organizations; which promote the creation of cooperation network (in a district and on the second level of local government administration);

- a creation of trade mark tourist products in region tourism, the rational and consolidated promotion of the products, a creation of a package with relation to a trademark product health and spa tourism;

- a growth of the amount of agro-tourist farms in the region;

- a growth of the number of accommodation objects (middle and high standard) in the region.

The implementation of the developmental plan should give a rise to a growth of enterprise in the sub-region and the creation of tourist innovative products, which allows for the strengthening of the regional position, as the strong tourist centre of southern Poland. The subjects of tourist, business surrounding play an important part in the process, 
as the creators of the economy based on knowledge. The authors of the study achieved their goal, set before working out on the article, and at the same time they indicate that scenario planning method is useful for drawing up the innovative development plan of tourist products. In this study it was not presented the complete method but the selected fragment in order to show its main mechanisms.

\section{LIST OF REFERENCES}

1. Broll R. (ed.): Gospodarka lokalna i regionalna w teorii i praktyce, Prace naukowe Uniwersytetu Ekonomicznego we Wrocławiu, No. 46, Wrocław 2009, p. 53, http://www. dbc.wroc.pl/Content/3957/PN_46.pdf, [2011-12-21].

2. Damanpour F.: Organizational complexity and innovation: Developing and testing multiple contingency models, "Management Science" 1996, No. 42.

3. Drucker P. F.: Praktyka zarządzania, AE, Kraków 1994.

4. Hjalager A.-M.: A Review of Innovation Research in Tourism, "Tourism Management" 2010, $\mathrm{Nr} 31$.

5. Hjalager A.-M.: Repairing innovation defectiveness in tourism, "Tourism Management" 2002, No 23.

6. Mang P.: Strategic Innovation: Constantinos Markides on Strategy and Management, "The Academy of Management Review" 2000, No. 14 (3).

7. Novelli M., Schmitz B., Spencer T., Networks, clusters and innovation In tourism: A UK experience, "Tourism Management" 2006, No. 27.

8. Pavitt K.: Sectorial patterns of technical change: Towards a taxonomy and a theory. "Research Policy 1984, No. 13(6).

9. Peters M., Pikkemaat B., Innovation in hospitality and tourism, The Haworth Hospitality Press, New York 2005.

10. Schumpeter J. A.: Teoria rozwoju gospodarczego, PWN, Warszawa 1960.

11. Sipe L.J., Testa M.: What is Innovation in the Hospitality and Tourism Marketplace? A Suggested Research Framework and Outputs Typology, International CHRIE ConferenceRefereed Track. Paper 22, http://scholarworks.umass.edu/refereed/Sessions/Friday/22/, [2011-12-08].

12. Stróżyński M.: Małe i średnie przedsiębiorstwa w świetle Strategii Lizbońskiej, Szkoła Główna Handlowa w Warszawie, Warszawa 2008.

13. Świtalski W., Innowacje i konkurencyjność, Wydawnictwo Uniwersytetu Warszawskiego, Warszawa 2005.

14. Wonglimpiyarat J., Yuberk $N$.: In support of innovation management and Roger's Innovation Diffusion theory, "Science Direct Government Information Quarterly" 2005, No 22.

Стаття: надійшла до редколегї̈ 28.05.2012 прийнята до друку 06.06.2012 


\title{
СЦЕНАРІЇ МАЙБУТНЬОГО - МОДЕЛЮВАННЯ ІННОВАЦІЙНИХ ПРОДУКТІВ ТУРИЗМУ
}

\author{
3. Зонтек, Є. Ліпьянін-Зонтек \\ Університет Бельсько-Бяла, Польща
}

Мета цієї статті полягає у вказівці напрямку розвитку туристичної галузі у південному регіоні Сілезькій області. У статті охарактеризовано суть моделювання інноваційних продуктів протягом усього життєвого циклу продукту. Представлені результати досліджень в регіоні та методи сценарного планування, використовувані для позначення основних змін в туристичному секторі - з особливим тиском на інноваційність.

Ключові слова: Туристичні продукти, інновації, майбутнє

\section{СЦЕНАРИИ БУДУЩЕГО - МОДЕЛИРОВАНИЕ ИННОВАЦИОННЫХ ПРОДУКТОВ ТУРИЗМА}

\author{
С. Зонтек, Е. Липьянин-Зонтек \\ Университет Бельско-Бяла, Польша
}

Цель этой статьи заключается в указании направления развития туристической отрасли в южном регионе Силезской области. В статье охарактеризовано суть моделирования инновационных продуктов в течение всего жизненного цикла продукта. Представлены результаты исследований в регионе и методы сценарного планирования, используемые для обозначения основных изменений в туристическом секторе - с особым давлением на инновационность.

Ключевые слова: Туристические продукты, инновации, будущее 